\title{
DISEMINASI INOVASI OLAHAN PRODUK MAKANAN BERBAHAN DASAR JAGUNG DI NAGARI GIRI MAJU KABUPATEN PASAMAN BARAT
}

\section{DISSEMINATION OF PROCESSED CORN-BASED FOOD PRODUCTS INNOVATION IN NAGARI GIRI MAJU, WEST PASAMAN REGENCY}

\author{
P.K. Dewi Hayati ${ }^{1 *}$, Aprialis $^{2)}$, Desi Liyana ${ }^{3)}$ dan Ira Desri Rahmi ${ }^{4)}$ \\ ${ }^{1)}$ Fakultas Pertanian, Universitas Andalas, email: pkdewihayati@agr.unand.ac.id \\ ${ }^{2)}$ Fakultas Teknologi Pertanian, Universitas Andalas, email: apri.alis96@gmail.com \\ ${ }^{3)}$ Fakultas Teknologi Pertanian, Universitas Andalas, email: desiliyana27@gmail.com \\ ${ }^{4)}$ Fakultas Teknologi Pertanian, Universitas Andalas, email: ira.desri@gmail.com
}

\begin{abstract}
ABSTRAK
Jagung merupakan tanaman serealea yang digunakan sebagai bahan baku industri pangan dan non-pangan. Biji jagung merupakan hasil panen tanaman jagung yang biasanya dijual dalam bentuk tongkol atau pipil. Sebagai penghasil jagung utama di Sumatera Barat, belum banyak produk olahan jagung yang ditemukan di Kabupaten Pasaman Barat. Kegiatan pemberdayaan masyarakat ini bertujuan untuk mendiseminasikan dan mendorong berbagai inovasi produk olahan makanan dari jagung pada masyarakat Nagari Giri Maju, Kabupaten Pasaman Barat melalui kegiatan Kuliah Kerja Nyata (KKN) Dikti. Metode diseminasi teknologi yang diterapkan adalah berupa demonstrasi dan pelatihan, penyuluhan dan pendampingan masyarakat. Hasil menunjukkan bahwa kegiatan yang dilakukan (1) berhasil mendiseminasikan berbagai inovasi produk makanan berbahan dasar jagung pipil dan tepung jagung, dan (2) masyarakat baru mampu berinovasi menghasilkan produk olahan jagung yang memiliki daya tahan/simpan yang rendah. Perlu dukungan pemerintah daerah dan partisipasi aktif masyarakat untuk keberlanjutan program menjadikan kabupaten Pasaman Barat tidak hanya sebagai penghasil jagung tetapi juga penghasil produk makanan olahan berbahan dasar jagung.
\end{abstract}

Kata kunci: Diversifikasi, Jagung pipil, Nilai tambah, Produk olahan jagung

\begin{abstract}
Corn is an important cereal crop used as the raw material of food and non-food industries. Grain kernel is the harvest of corn plants. As the leading producer of corn in West Sumatera, there are not many processed corn products found in West Pasaman Regency. The community empowerment aimed to disseminate and encourage various innovations processed food products from corn in the Nagari Giri Maju, West Pasaman Regency, through the activities of KKN Dikti. The method of dissemination of technology applied is a demonstration, in-house training, community learning and assistance. Results showed that activities conducted (1) successfully disseminated various innovations of food products based on corn kernel and cornflour, and (2) the community was able to produce cornprocessed products that have a low durability/shelf life. To sustain the program that makes the West Pasaman regency as the producer of processed corn products need local government support and active participation of the community.
\end{abstract}

Keywords: Diversification, Corn kernel, Value added, Corn processed 


\section{PENDAHULUAN}

Jagung merupakan tanaman pangan utama setelah padi di Indonesia. Tidak hanya sebagai bahan pangan, jagung juga digunakan sebagai bahan baku industri baik industri pangan maupun non-pangan seperti industri pakan. Jenis jagung yang mendominasi perdagangan dunia dan paling banyak dibutuhkan bagi keperluan industri adalah jagung pipil [1]. Jagung pipil merupakan biji jagung (maize kernel) yang diperoleh dari pemipilan tongkol (pod) jagung yang telah matang.

Kabupaten Pasaman Barat merupakan kabupaten penghasil jagung terbesar di propinsi Sumatera Barat dengan produksi sebesar 367.865 ton pada tahun 2018 [2]. Namun walaupun dikenal sebagai kabupaten jagung, tidak banyak produk olahan jagung ditemui di kabupaten penghasil jagung tersebut. Sebagian besar produksi jagung dari Pasaman Barat dijual dalam bentuk pipilan ke Kabupaten Lima Puluh Kota atau Padang Pariaman untuk memenuhi kebutuhan industri pakan ternak [3].

Pada dasarnya jagung dapat diolah menjadi berbagai produk makanan, mulai dari olahan tradisional, semi tradisional hingga modern. Produk olahan jagung pada apapun tingkatannya memiliki nilai jual yang lebih tinggi dibandingkan ketika jagung dijual sebagai pipilan. Upaya untuk mengolah jagung pipil yang pada awalnya bernilai harga rendah (2800 - 3500 rupiah per $\mathrm{kg}$ ) menjadi berbagai produk olahan makanan sehingga nilai jualnya lebih tinggi merupakan upaya peningkatan nilai tambah. Menurut [4] nilai tambah merupakan pertambahan nilai suatu komoditas karena adanya input fungsional yang diberlakukan pada komoditas tersebut, baik berupa proses perubahan bentuk (form utility), pemindahan tempat (place utility), maupun penyimpanan (time utility).

Agroindustri jagung sudah berkembang pesat saat ini, namun tidak semua teknologinya dapat diterapkan ke semua lapisan masyarakat. Pengolahan jagung menjadi berbagai produk olahan makanan dapat menjadi peluang kerja bagi perempuan dan ibu rumah tangga karena menggunakan teknologi yang sebenarnya sudah ada di masyarakat. Produk inovasi produk jagung dengan teknologi tepat guna perlu dikenalkan ke masyarakat, termasuk cara pengolahan, peralatan yang dibutuhkan, pengemasan dan bagaimana pemasaran produknya. Oleh karena itu kegiatan pemberdayaan masyarakat yang dilakukan bertujuan untuk mendiseminasikan dan mendorong berbagai inovasi produk olahan makanan dari jagung pipil pada masyarakat penghasil jagung di Nagari Giri Maju, Kabupaten Pasaman Barat. 


\section{METODE PELAKSANAAN} KEGIATAN

Metode Kegiatan pemberdayaan masyarakat telah dilakukan oleh dosen dan mahasiswa melalui kegiatan KKN (Kuliah Kerja Nyata) Program Pembelajaran dan Pemberdayaan Masyarakat Tematik Dikti. Kegiatan dilakukan dari bulan April hingga Agustus 2018 dengan pelaksanaan KKN berlangsung pada Juni - Agustus 2018. Masyarakat mitra adalah masyarakat Nagari Persiapan Giri Maju, kecamatan Luhak Nan Duo, Kabupaten Pasaman Barat, Propinsi Sumatera Barat. Nagari baru ini terdiri atas 10 dusun yang penghasilan utama masyarakatnya adalah dari komoditas jagung, sawit dan alpukat.

Tahapan persiapan inovasi produk; meliputi tahapan mahasiswa membekali diri dengan pengetahuan dan keterampilan mengenai pengolahan jagung menjadi berbagai produk. Tahapan ini dilakukan dalam bentuk pembekalan materi oleh dosen ahli, uji coba pembuatan berbagai produk makanan olahan jagung, dan penyediaan berbagai kemasan dan label untuk setiap produk. Sosialisasi kegiatan; dilakukan di kantor walinagari yang dihadiri oleh wali nagari serta perangkat nagari. Sosialisasi kegiatan juga dilakukan pada masingmasing kelompok kerja yang meliputi gabungan dari 3-4 dusun. Diseminasi teknologi; dilakukan dengan menggunakan metode demonstrasi dan pelatihan, penyuluhan, dan pendam-pingan masyarakat. Evaluasi; dilakukan untuk menilai seberapa besar kemampuan inovasi masyarakat dalam menghasilkan produk olahan berbahan dasar jagung dalam bentuk lomba masak produk olahan jagung yang diikuti oleh seluruh dusun.

\section{HASIL DAN PEMBAHASAN}

Karbohidrat mendominasi kandungan nutrisi dari biji jagung yang ditepungkan, walaupun sebenarnya biji jagung juga mengandung protein, lemak, serat pangan, beberapa mineral dan vitamin. Selain itu jagung juga mengandung fitokimia penting yang terdiri dari karotenoid, fenolik dan fitosterol [5]. Kandungan karbohidrat yang tinggi beserta kandungan nutrisi penting lainnya menjadikan jagung sebagai bahan baku produk pangan berbahan dasar jagung.

Pengolahan jagung menjadi berbagai produk olahan makanan dapat menjadi peluang kerja bagi perempuan dan ibu rumah tangga lainnya. Dengan demikian hal ini akan meningkatkan angka partisipasi kerja perempuan. Adanya produk olahan jagung dapat meningkatkan pendapatan keluarga, sekaligus bisa menjadi usaha skala rumah tangga dengan seluruh aspek komersialnya melalui teknik pengolahan, pengemasan dan manajemen pemasarannya.

Tahapan persiapan yang berlangsung selama tiga bulan memberikan waktu yang cukup untuk berinovasi menghasilkan berbagai produk olahan jagung. Produk ini kemudian didiseminasikan kepada 
masyarakat Nagari Giri Maju terutama ibuibu rumah tangga yang tergabung dalam PKK dan remaja putri. Kegiatan demonstrasi dan praktek bersama masyarakat (pelatihan) dilakukan dalam pembuatan berbagai produk olahan makanan. Kegiatan juga diikuti dengan penyuluhan mengenai keamanan produk pangan, pengemasan dan pelabelan produk, pembuatan analisis usaha secara sederhana serta peluang pemasaran dilakukan pada setiap kelompok kerja yang dibagi atas 3-4 dusun (Gambar 1). Kegiatan pendam-pingan juga dilakukan pada beberapa anggota/kelompok masyarakat yang menun-jukkan minat terhadap pengembangan usaha pengolahan jagung lebih lanjut.
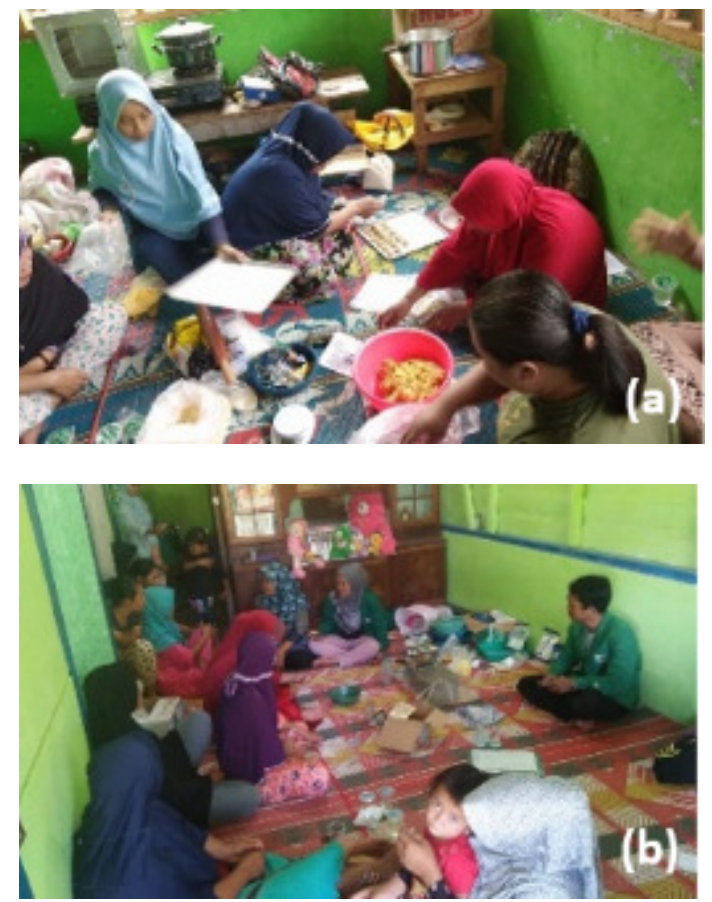

Gambar 1. Kegiatan diseminasi

a) Praktek bersama pembuatan produk olahan jagung, b) Penyuluhan keamanan pangan dan pemasaran Berdasarkan bahan baku yang diguna- kan, pada dasarnya produk olahan dapat dikelompokkan atas 2 bagian, yaitu produk berbahan dasar jagung pipil atau biji jagung dan yang berbahan dasar tepung jagung (Tabel 1). Masyarakat selama ini sudah mengenal produk yang dibuat langsung dari biji jagung yaitu tojin atau marning jagung, dan emping jagung. Inovasi produk olahan yang belum dikenal masyarakat secara luas adalah tepung jagung.

Tabel 1. Berbagai Inovasi Produk Olahan

\begin{tabular}{|c|c|c|}
\hline \multicolumn{3}{|c|}{ Jagung } \\
\hline No & Bahan dasar & Produk \\
\hline \multirow[t]{5}{*}{1} & Jagung Pipil & 1. Tepung jagung \\
\hline & & 2. Tempe \\
\hline & & 3. Sempol \\
\hline & & 4. Bola-bola \\
\hline & & jagung \\
\hline \multirow[t]{9}{*}{2} & Tepung & 1. Kukis \\
\hline & Jagung & 2. Dodol \\
\hline & & 3. Donat \\
\hline & & 4. Sala \\
\hline & & 5. Mie \\
\hline & & 6. Kerupuk \\
\hline & & 7. Stik \\
\hline & & 8. Tortila \\
\hline & & 9. Puding \\
\hline
\end{tabular}

Tepung jagung adalah tepung yang diperoleh dari proses penggilingan biji jagung menjadi tepung. Tepung jagung dapat mensubstitusi tepung terigu sebagian atau keseluruhan dalam pembuatan berbagai produk makanan. Campuran tepung jagung bersama dengan tepung lainnya, baik dengan terigu atau non-terigu menghasilkan tepung komposit [6]. Tepung jagung dengan campuran terigu, beras, ketan atau singkong menjadi bahan dasar dari berbagai produk inovasi olahan 
makanan berbahan dasar jagung.

Produk tepung jagung membutuhkan serangkaian peralatan/mesin yang memproses tongkol jagung yang dihasilkan oleh petani menjadi tepung. Tongkol yang sudah dikeringkan dipipil menggunakan mesin pemipil jagung. Mesin pemipil berdaya 7 hp sudah cukup memadai untuk dimanfaatkan oleh kelompok tani menampung hasil panen anggota kelompok. Keberadaan mesin pemipil dilaporkan oleh [7] mampu menurunkan biaya produksi sehingga keuntungan yang diperoleh petani meningkat sejalan dengan peningkatan harga jual pipilan jagung. Pipilan jagung selanjutnya diolah menjadi tepung menggunakan mesin penepung yang juga berdaya $7 \mathrm{hp}$. Kehalusan tepung dapat diatur menggunakan saringan $80-120$ mesh tergantung pada produk yang akan dibuat.

Masyarakat tetap dapat mengolah jagung pipil menjadi berbagai produk walaupun mesin pemipil dan mesin penepung tidak dimiliki. Jagung pipil dapat dibeli ke pedagang pengumpul jagung. Jika mesin penepung tidak tersedia, masyarakat masih dapat mengupahkan penggilingan ke kedai penepung yang biasanya menerima upah penepungan untuk beras.

Produk olahan makanan berbahan dasar jagung merupakan solusi inovatif untuk menghasilkan nilai tambah. Nilai tambah merupakan selisih harga yang diterima atas perlakuan tertentu dengan harga jagung pipil. Upaya peningkatan nilai tambah produk juga memberikan kesempatan kepada keluarga petani untuk memperoleh keuntungan yang lebih besar di samping memicu tumbuhnya sektor UMKM, khususnya UMKM yang bergerak pada bidang produksi makanan khas berbahan dasar jagung.

Produk olahan jagung sangat bervariasi mulai dari produk yang mudah dalam pembuatannya seperti kukis dan kerupuk, hingga produk yang membutuhkan keteram-pilan lebih seperti dodol dan mie. Berbagai variasi produk diharapkan menarik minat konsumen untuk menikmati produk tersebut. [8] menyatakan bahwa semakin tinggi nilai tambah yang dimiliki oleh suatu produk maka kepuasan konsumen akan semakin tinggi pula. Dengan demikian, penghargaan konsumen terhadap produk tersebut tentu akan semakin tinggi yang ditandai dengan peningkatan harga yang dibayarkan oleh konsumen terhadap produk.

Upaya untuk memasyarakatkan produk olahan jagung adalah dengan mengadakan ekspo produk olahan jagung dan lomba memasak produk olahan jagung (Gambar 2). Ekspo produk olahan jagung yang merupakan bagian dari ekspo KKN, menampilkan segala produk hasil kegiatan KKN dihadiri oleh Bupati Pasaman Barat. Ekspo produk olahan jagung merupakan 
upaya untuk lebih mengenalkan berbagai produk olahan jagung ke masyarakat luas, tidak hanya kepada petani jagung tetapi juga kepada konsumen dengan pangsa pasar yang lebih luas. Kegiatan ekspo diliput secara luas oleh media massa sehingga diharapkan produk olahan jagung dapat lebih memasyarakat.

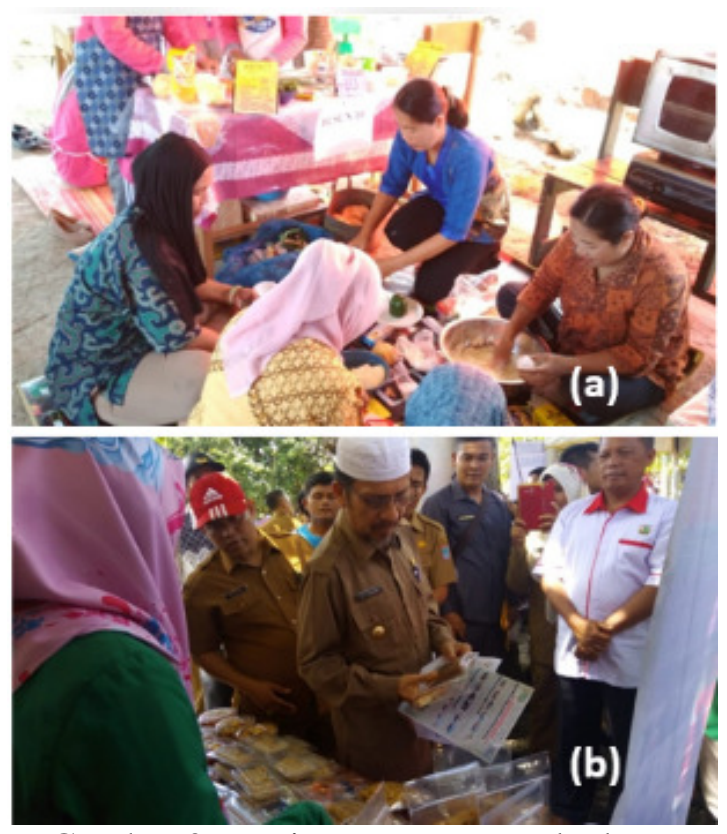

Gambar 2. Kegiatan memasyarakatkan produk olahan jagung

a) Lomba memasak olahan jagung, b) Ekspo produk olahan jagung KKN Universitas Andalas

Lomba memasak produk olahan jagung selain memasyarakatkan produk olehan jagung juga bertujuan untuk mengevaluasi kemampuan inovasi masyarakat dalam menghasilkan produk olahan jagung. Lomba ini diikuti oleh perwakilan dari setiap dusun yang ada di Nagari Giri Maju. Berdasarkan produk olahan jagung hasil inovasi masyarakat, diperoleh sebanyak 14 produk. Produk tersebut adalah bubur jagung, tumpeng nasi jagung, lele geprek, mie pangsit jagung, spaghetti, biji salak, cenil, pizza, brownies, bolu, kroket, lepat, gelamai dan donat jagung. Beberapa produk olahan jagung hasil inovasi dari masyarakat tersebut ditampilkan pada Gambar 3.
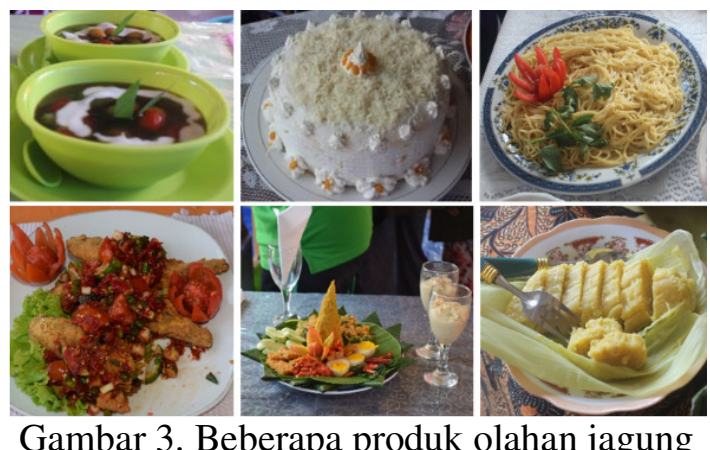

Gambar 3. Beberapa produk olahan jagung hasil inovasi masyarakat

Seluruh produk yang dihasilkan masyarakat merupakan produk yang berbahan dasar tepung jagung. Dua produk yaitu lepat dan pergedel jagung juga menggunakan biji jagung yang masih muda, disamping tepung jagung. Berdasarkan penilaian dari tim juri yang melibatkan Dinas Kesehatan dan Dinas Pangan Kabupaten Pasaman Barat, seluruh produk memenuhi kriteria diversifikasi pangan. Diversifikasi pangan yang dilakukan tidak saja mengarah kepada upaya mengurangi ketergantungan masyarakat terhadap beras sebagai makanan pokok tunggal, tetapi juga mengarah kepada diversifikasi bentuk produk olahan. Produk juga memiliki penampilan yang menarik disamping tetap mempertahankan kandungan gizi sebagai produk pangan yang aman dan sehat.

Semua produk olahan hasil inovasi masyarakat merupakan produk yang memiliki sifat tidak tahan lama, kecuali 
gelamai. Gelamai adalah produk seperti dodol, namun memiliki tekstur yang lebih lunak. Jenis produk yang dihasilkan oleh masyarakat mengindikasikan bahwa walaupun masyarakat sudah mampu menghasilkan dan menampilkan produk olahan jagung dengan baik, namun masyarakat belum mampu melakukan inovasi terhadap produk yang tahan lama. Produk yang tahan lama lebih memiliki peluang untuk dipasarkan melalui perantara seperti swalayan atau toko lainnya dibandingkan produk yang daya tahannya hanya beberapa hari (perishable).

\section{KESIMPULAN}

Berdasarkan kegiatan yang telah dilaksanakan, dapat disimpulkan bahwa (1) Berbagai inovasi produk makanan berbahan dasar jagung pipil dan tepung jagung telah berhasil didiseminasikan selama kegiatan, dan (2) masyarakat baru mampu berinovasi menghasilkan produk olahan jagung yang memiliki daya tahan/simpan yang rendah.

\section{SARAN}

Berbagai produk olahan jagung dimasyarakatkan secara luas melalui kegiatan ekspo produk olahan jagung. Namun untuk keberlanjutan program menjadikan kabupaten Pasaman Barat sebagai penghasil produk makanan olahan berbahan dasar jagung, dibutuhkan partisipasi aktif masyarakat pada semua lapisan dan dukungan pemerintah daerah.

\section{UCAPAN TERIMAKASIH}

Kegiatan ini didanai oleh DRPM Kementerian Riset, Teknologi dan Pendidikan Tinggi tahun 2018. Ucapan terima kasih disampaikan kepada LPPM dan PU KKN Universitas Andalas, Bupati Pasaman Barat: Drs. Syahiran MM, Kadis Pertanian Tanaman Pangan, Hortikultura dan Peternakan: Sukarli, SPt. MSi, Camat Luhak Nan Duo: Ahmad Hanif, S.IP, perangkat nagari Giri Maju, kepala dan warga dusun 1 - 10 Nagari Persiapan Giri Maju.

\section{REFERENSI}

[1] USDA-FAS. 2018. Indonesia Grain And Feed Annual Report. https://gain.fas.usda. gov/Recent\%20GAIN\%20Publication s/Grain\%20and\%20Feed\%20Annual_ Jakarta_Indonesia_3-29-2018.pdf [diakses 20 September 2019]

[2] BPS Sumatera Barat. 2020. Produksi Jagung Provinsi Sumatera Barat. https://sumbar.bps.go.id/dynamictable /2016/12/13/66/produksi-jagungprovinsi-sumatera-barat-menurutkabupaten-kota-ton-2000-2018.html [diakses 20 Februari 2020]

[3] Dewi-Hayati, P.K. Efendi, S. Rahmi, I.D dan Saputra, R. 2018. PemberDayaan Masyarakat Nagari Persiapan Giri Maju, Kabupaten Pasaman Barat Dengan Inovasi dan Teknologi PengOlahan Jagung. Bul. Ilmiah Nagari Membangun. 1(3):1-14

[4] Hayami, Y. Toshihiko, K. Yhosinori, M. dan Masdjidin, S. 1987. Agricultural Marketing and Processing in Upland Java: A Prospectif From A Sunda Village, Bogor. CGPRT No 8. Bogor

[5] Shah, T.R., Prasad K. and Kumar, P. 2016. Maize - A Potential Source of Human Nutrition and 
Health: A Review. Cogent Food \& Agric. 2:1-9.

[6] Sitanggang, A.B. 2016. Tepung KomPosit Sebagai Alternatif Komponen Utama Produk Bakeri. Foodreview Indonesia. 11(12):52-55

[7] Dewi-Hayati, P.K., Prasetyo, T.B. dan Evalia, N.A. 2016. Penerapan Ipteks untuk Pengembangan Jagung Secara
Intensif pada Lahan Sawit Replanting di Kabupaten Pasaman Barat. Prosiding Seminar Nasional PKM dan CSR. Padang, 23 - 24 Oktober 2016

[8] Hasanah, U., Mayshuri, Djuwari. 2015. Analisis Nilai Tambah Agroindustri Sale Pisang di Kabupaten Kebumen. Jurnal Ilmu Pertanian. 18(3):141-149. 